\title{
ANALISIS HUBUNGAN SERTIFIKASI ISO 9000 \\ DENGAN EARNING PER SHARE (EPS) \\ PERUSAHAAN MAKANAN DAN MINUMAN DI INDONESIA
}

\author{
Indah Yuliana \\ Fakultas Ekonomi Universitas Islam Negeri (UIN) Malang \\ J1. Gajayana No. 50, Telepon (0341) 558881, Fax. (0341) 558881, \\ E-mail: feuinmlg@yahoo.co.id
}

\begin{abstract}
Pursuant to analysis result of research, hence can be pulled conclusion as follows: Mean of percentage of company which don't have ISO certification 9000 experiencing of increase equal to $27,21 \%$ the increase smaller relative in comparison with the percentage of mean increase of sale of company which have had certificate of ISO 9000. But that increase do not enjoy by all companies owning certification. Company owning ISO certification 9000 year 1994 having the percentage of biggest improvement that is 63, 51\%. Company getting ISO certification 9000 for year 1995 experiencing of the percentage of improvement equal to 9,99\% and also for company which have got ISO certification 9000 for year 1996 experiencing of the percentage of degradation equal to $0,69 \%$.

Pursuant to analysis of ANOVA known that there are difference of EPS of company which do not have ISO 9000 with company getting ISO 9000 year 1994, 1995 and 1996.

Pursuant to result test Duncan can know that fourth above company category can be differentiated to become two group, first group of company getting ISO 1996, 1995 and which do not get ISO certification 9000. This matter is caused by company which don't have ISO certification 9000 ( Mayora INDO, fresh of sea, Industrial Ultra Djaya Milk, Ades Alfindo, Endless Davomas and Multifarious Prasidina of Commercial) and company getting ISO 9000 year 1995 and 1996 owning average value of earning per share the nearbyness or one group.while second group is company which do not get ISO certification 9000 and company getting ISO 1994. Matter this means there are some companies which not yet got ISO 9000 but have value of ESP the highness that is company of Delta of Djakarta and of Multi Star of INDO.

Pursuant to correlation analysis of rank spearmen's known that earning per company share have relation with ISO certification 9000 (for company getting ISO certification 9000 in the year 1994).
\end{abstract}

Key words: quality of, certification ISO 9000, earning per share (ESP).

Dalam persaingan yang makin padat, mutu merupakan isu paling dominan pada banyak perusahaan. Mutu dari suatu produk yang ditawarkan akan memiliki peranan yang sangat strategis terhadap perkembangan bisnis. 
Mutu yang baik tidak akan dapat diraih hanya dengan mengandalkan keberuntungan semata, tapi mutlak harus dengan cara penerapan manajemen bisnis yang baik. Bersamaan dengan waktu, perusahaan selalu dituntut untuk membuat produk yang selalu sesuai dengan yang diminta oleh konsumen. Mutu merupakan pilihan kunci yang strategis.

Mutu mempengaruhi seluruh organisasi, dari pemasok sampai konsumen, dan dari rancangan produk sampai aspek dalam pemeliharaan peralatan. Makna mutu atau kualitas sendiri sangat erat kaitannya dengan tingkat kesempurnaan, kesesuaian dengan kebutuhan, bebas dari cacat, ketidaksempurnaan atau kontaminasi, serta kemampuan memuaskan konsumen. Konsumen merupakan pihak yang paling tepat dan adil dalam menilai masalah mutu dari produk atau layanan yang disediakan. Suatu produk atau layanan yang memiliki fitur atau manfaat yang tidak memuaskan konsumen dapat disebut dengan produk yang tidak bermutu.

Produk dan jasa yang bermutu secara strategis penting bagi perusahaan dan negara yang diwakilinya. Mutu dari produk suatu perusahaan, harga yang ditetapkan oleh perusahaan, dan pemasokan barang yang membuat produk itu tersedia bagi konsumen merupakan faktor-faktor yang menentukan permintaan. Ada enam tantangan yang dihadapi oleh Indonesia dalam memasuki era globalisasi, yaitu : (1) perubahan yang begitu cepat, yang merupakan dampak kemajuan ilmu pengetahuan dan tehnologi, (2) makin tajam dan tingginya persaingan produk, jasa modal dan kreatifitas manusia sebagai komoditi pasar modal, (3) keunggulan daya saing ditentukan oleh faktor desain, mutu barang, pengembangan produk, input tehnologi, nilai tambah, harga, penyerahan tepat waktu, pelayanan purna jual, (4) makin tingginya tuntutan sumber daya manusia, sebagai manusia modal: sumber daya manusia yang profesional, berkualitas, disiplin, produktif dan kreatif, (5) setiap komoditi ekspor untuk pasar modal, dituntut untuk memenuhi standar internasional ISO-WTO, (6) terjadi perubahan paradigma ekonomi bukan lagi apa yang dapat diproduksi, bagaimana memproduksi dan untuk siapa (what, how dan for, whom) tetapi dibalik : for who (pemasaran), how (bagaimana memproduksinya, sumber daya ekonomi), kemudian what kind of product will be produced (Sagir, 1997:3). 
Dari enam tantangan tersebut, kehandalan tehnologi tanpa disertai cost effectiveness (non high cost economy), tidak menjamin produk tersebut laku terjual di pasar global, jika tidak memenuhi desain yang sesuai selera konsumen, mutu yang tinggi, tidak hanya mmproduksi tetapi dapat terjual dan diekspor ke pasar global. Meningkatnya volume perdagangan internasional serta makin pentingnya perdagangan internasional bagi bangsa di dunia membuat kita percaya bahwa perkembangan perdagangan bebas adalah sesuatu yang tidak dapat dihindari.

Ekspor Indonesia berupa produk makanan dan minuman sejak tahun 1992-1997 tercatat 1.278 jenis produk tertahan, 24 diantaranya dengan tujuan Australia. Negara yang menolak impor Indonesia selain Australia adalah Uni Eropa, Amerika dan Jepang, khususnya produk perikanan. Alasan utamanya adalah produk perikanan di Indonesia diantaranya udang belum memenuhi standar internasional. Penilaian asing yang demikian ini jelas akan mempengaruhi ekspor produk makanan dan minuman di Indonesia yang menggunakan bahan baku hasil perikanan lokal (Darmawan, 1999:50-55).

Mengapa standarisasi itu penting? Sebagai pembeli/pengguna suatu produk tentunya kita akan merasa sangat tertanggu dan kecewa ketika produk yang telah dibeli tersebut ternyata memiliki kualitas yang sangat buruk, tidak layak pakai, tidak cocok dengan peralatan yang telah kita miliki sebelumnya, mudah rusak, atau berbahaya jika digunakan, demikian pula sebaliknya. Itulah sebagian gambaran dimana kita kurang peduli terhadap peran dari suatu standar sistem mutu dalam meningkatkan level kualitas/mutu, keamanan, ketahanan, efisiensi dan interchange ability dari suatu produk yang kita gunakan.

Tujuan dalam penelitian ini adalah (1) Untuk mengetahui perkembangan rata-rata earning per share perusahaan makanan dan minuman di Indonesia (2) Untuk mengetahui perbedaan earning per share antara perusahaan yang mendapatkan sertifikasi ISO 9000 dan perusahaan yang tidak mendapatkan ISO 9000 pada perusahaan makanan dan minuman di Indonesia (3) Untuk mengetahui pengelompokan perusahaan makanan dan minuman di Indonesia berdasarkan kategorinya (4) Untuk mengetahui hubungan antara earning per share dengan sertifikasi ISO 9000 pada perusahaan makanan dan minuman di Indonesia 


\section{KUALITAS DAN DAYA SAING}

Bagi perusahaan, baik manufaktur ataupun jasa. Penyediaan produk yang berkualitas memang telah menjadi tuntutan agar dapat bertahan hidup dalam persaingan. Makin meningkatnya daya beli dan didukung oleh makin dewasanya konsumen baik secara budaya maupun pengetahuannya membuat permintaan mereka terhadap kualitas produk semakin meningkat. Konsep mengenai kualitas sangat luas sekali cakupannya. Pelanggan dalam mendefinisikan kualitas dengan barbagai cara, dalam melakukan pembelian terhadap suatu produk entah itu berbentuk barang atau jasa, mereka berharap apa yang dibelinya memenuhi tingkat penampilan tertentu yang diiklankan. Ibrahim mengemukakan bahwa kualitas adalah suatu strategi dasar bisnis yang menghasilkan barang dan jasa yang memenuhi kebutuhan dan kepuasan konsumen internal dan eksternal, secara implisit dan eksplisit (Ibrahim, 1997:1337). Namun demikian secara obyektif pengertian kualitas adalah suatu standar khusus dimana kemampuannya (availability), kinerja (performance), keandalannya (reliability), kemudahan pemeliharaan (maintainability), dan karakteristiknya dapat diukur (Yamit, 1998:337). Dalam istilah perbendaharaan International Organization for Standardization (ISO), kualitas adalah keseluruhan ciri dan karakteristik produk atau jasa yang kemampuannya dapat memuaskan kebutuhan, baik yang dinyatakan secara tegas maupun tersamar (Yamit, 1998:337)

Dalam Islam kualitas produk itu harus benar-benar memenuhi syarat berkualitas, dalam artian bila barang tersebut tidak berkualitas atau cacat harus diutarakan, karena konsumen sering tertipu oleh perilaku-perilaku pedagang. Dimana konsumen mengira bahwa barang tersebut baik kualitasnya, namun pada kenyataannya sebaliknya. Bila barang tersebut ada yang berkualitas dan ada yang tidak maka harus dijelaskan atau disendirikan biar konsumen mengetahuinya, karena hal itu dilarang oleh Islam . Juga dijelaskan dalam hadits riwayat Uqban, yang artinya :

Muslim itu adalah saudara muslim, dan tidak boleh bagi seorang muslim apabila ia berdagang dengan saudaranya dan menemukan cacat, kecuali diterangkan.

Dalam surat Albaqarah ayat 42 disebutkan, yang artinya : 
Dan jangan kamu campur adukkan yang hak dengan yang bathil dan jangan kamu sembunyikan yang hak itu sedang kamu mengetahuinya (Al-Baqarah : 42)

Dalam Islam dilarang menyembunyikan barang cacat untuk mendapatkan harga yang tinggi. Ibnu Majah meriwayatkan dari Uqbah bin Amir dari Rasulullah saw yang mengatakan:

"Seorang adalah saudara bagi muslim yang lain. Dan tidak halal bagi seseorang untuk menjual barang kepada saudaranya sementara di dalamnya terdapat cacat, selain dia menjelaskan cacat kepadanya".

Dan dalam hadits yang lain Imam Bukhari meriwayatkan dari Hakim bin Hazzam dari Rasulullah saw mengatakan," pembeli dan penjual itu boleh memilih, selama keduanya belum terpisah. Apabila keduanya jujur, dan samasama menjelaskan (cacatnya), maka keduanya diberikan dalam jual belinya. Apabila keduanya menyembunyikan (cacatnya) dan berdusta, maka barakah jual belinya akan dicabut.

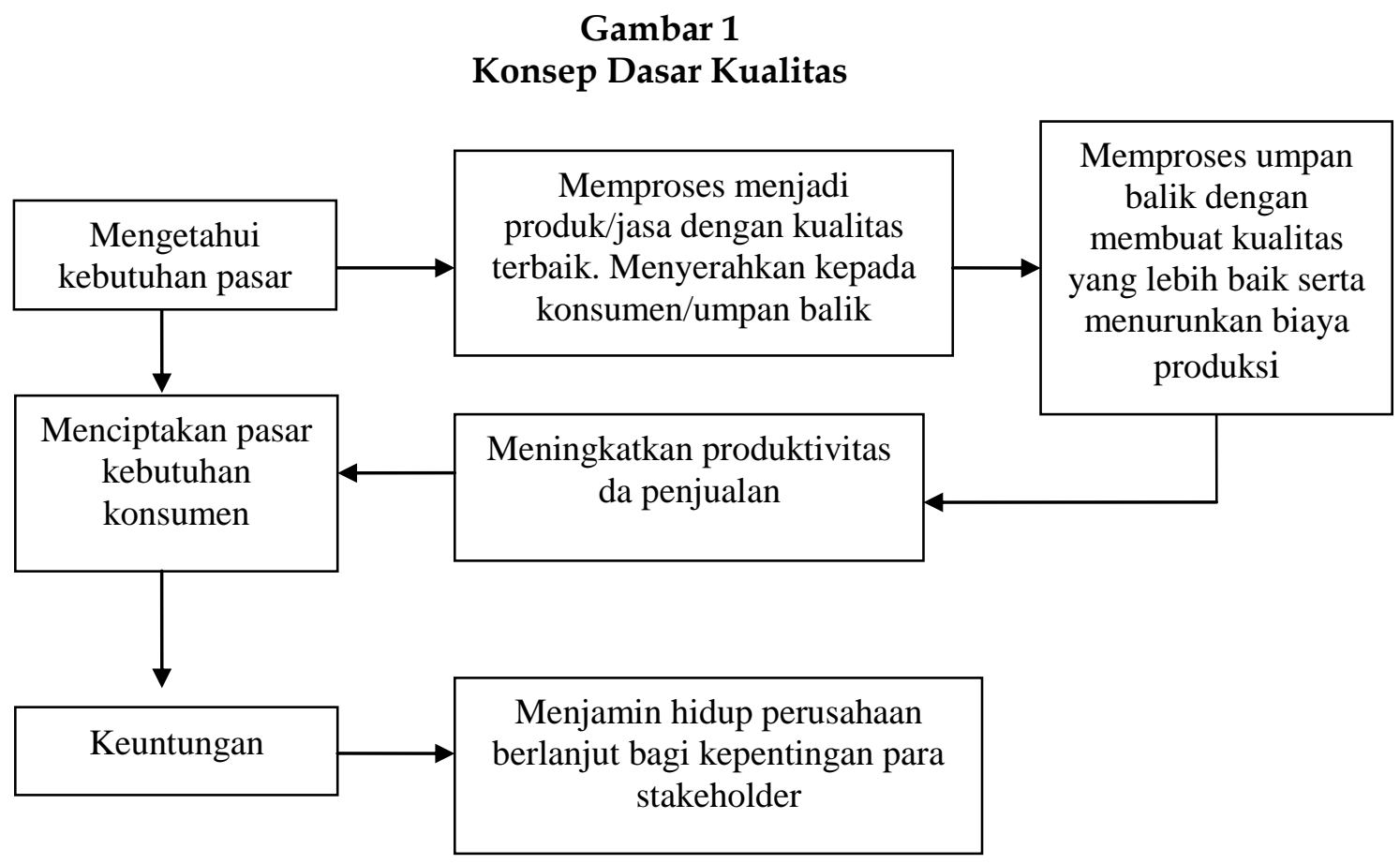

Sumber: (Ibrahim ,1997:6)

Ada beberapa hal yang melatarbelakangi mengapa kualitas diperlukan, yaitu:

1. Konsumen menjadi lebih canggih dalam selera dan pilihan

2. Kompetisi persaingan menjadi lebih ketat dan kompetitif

3. Kenaikan biaya yang bisa diatasi lewat perbaikan kualitas proses dan peningkatan produktifitas tanpa hentinya 
4. Krisis, apapun bentuknya apakah dari pihak pemasok, bank, tehnologi proses, pasar konsumen yang labil (Ibrahim, 1997:4)

Karakteristik dari suatu produk dipengaruhi oleh seluruh proses operasi, mulai dari kualitas bahan baku, ketrampilan dan kemampuan tenaga kerja, peralatan hingga faktor-faktor yang mendukung sistem operasi. Tidak ada satupun yang betul-betul tampak cukup meyakinkan apakah kualitas yang dibayar lebih rendah dari yang sebenarnya atau apakah sesuatu yang diperoleh sesuai dengan uang yang dikeluarkan untuk memperolehnya. Ada tiga ukuran yang dapat digunakan untuk barang, yaitu:

1. Kualitas desain (design quality)

Kualitas desain barang sangat berhubungan dengan sifat-sifat keunggulan pada saat barang yang semula diimpikan. Kualitas desain dipengaruhi oleh beberapa faktor, yaitu: (a) kualitas input, (b) teknologi yang digunakan, (c) kualitas tenaga kerja dan manajer.

2. Kualitas penampilan (performance quality)

Aspek ini mencakup performance produk di masa yang akan datang, yang dipengaruhi oleh dua faktor, yaitu keandalan produk (reliability of product) dan perawatan produk (maintenance of product).

3. Kualitas yang memenuhi (corformance quality)

Berhubungan dengan apakah produk yang dihasilkan memenuhi spesifikasi yang telah ditetapkan atau yang diharapkan, dengan kata lain sejauhmana kualitas suatu produk dapat dicapai. Dalam hal ini terdapat tiga faktor yang mempengaruhi conformance quality yaitu, (1) usia teknik produk (technical life of product), (2) pengaruh produk (impact of product), (3) ketepatan produk (accuracy of product) (Yamit, 1998 :338)

Tujuan dari jaminan kualitas dalam lingkungan perusahaan kelas dunia tidak hanya menolak produk cacat, tetapi secara sistematis mencari penyebab cacat sehingga bisa dieliminasi secara gradual. Tujuannya adalah nol cacat (zero defect), metodenya adalah perbaikan berkelanjutan (continous improvement) (Wibisono, 1999: 41). Keinginan dan persyaratan yang diminta konsumen seharusnya mendapat perhatian yang cermat, dan barang yang dibuat perlu disesuaikan dengan selera mereka. 


\section{ISO 9000}

Lingkungan dunia usaha telah mengalami perubahan yang cepat terutama dalam satu dasawarsa terakhir. Perubahan ini menuntut perusahaan untuk dapat memberikan pelayanan yang memuaskan kepada konsumen, sehingga perusahaan dapat bersaing dengan efektif dalam lingkungan global. Salah satu kunci sukses agar dapat bersaing di pasar global adalah kemampuan untuk memenuhi atau melampaui standar yang berlaku.

Untuk membuktikan ke seluruh dunia bahwa mutu produk suatu perusahaan terjamin, dewasa ini ISO 9000 memainkan peranan penting. Dalam buku ISO 9000, An Implementation Guide for Small to Mid Size Business, karangan Frank menyebutkan bahwa ISO (International Organization for Standardization) merupakan federasi dunia dari lembaga-lembaga standarisasi nasional dari 90 negara. Tujuan dari ISO 9000 adalah untuk mempromosikan arus pertukaran barang dan jasa internasional melalui pengembangan standarisasi (Soemardi, 1992: 45). ISO 9000 adalah kumpulan standar sistem kualitas universal, memberikan rerangka yang sama bagi jaminan kualitas yang dapat dipergunakan di seluruh dunia (Tjiptono, 2000: 87).

Dalam pasar global dewasa ini menurut John Hinds dari Amerika Serikat, ISO merupakan keharusan kompetitif. ISO 9000 merupakan serangkaian standart yang menentukan dokumentasi suatu program kualias. Perusahaan menjadi terjamin dengan memberikan bukti, bahwa mereka telah memenuhi semua persyaratan. Apabila sudah mendapatkan jaminan, perusahaan tersebut terdaftar dalam sebuah directory sehingga para pelanggan potensial bisa melihat perusahaan-perusahaan yang telah mendapatkan jaminan dan pada tingkat yang sama (Krajewski, 1996:169). ISO 9000 merupakan sistem mutu. Sistem tersebut akan melibatkan standar produk individual dan kalibrasi serta pengukuran. Keseluruhan sistem bermanfaat untuk menjamin berlangsungnya operasi secara terus menerus dari seluruh proses, dari pembelian bahan baku sampai pengiriman produk jadi akhir.

Standar ISO dipopulerkan dalam enam dokumen yang terpisah dengan nomor ISO 8402, ISO 9000, ISO 9001, ISO 9002, ISO 9003 dan ISO 9004 (Herdiwiardjo, 1996: 23). ISO 9000 adalah suatu rangkaian dari lima standar internasional yang dikembangkan oleh International Organization for 
Standarization di Jenewa Swiss. Program ini diprakarsai American National Organization Institute (ANSI) yang berkedudukan di New Jersey. Seri standar diberi nama sedemikian rupa sehingga terdiri dari lima set standar atau kriteria dengan kondifikasi angka yang berurutan mulai dari ISO 9000, yang merupakan peta jaringan yang memberikan definisi dasar dan konsep-konsep serta menerangkan bagaimana memilih dan menggunakan standar-standar lain dalam seri tersebut.

Standar-standar seperti ISO 9000 dikritik oleh beberapa ahli sebagai suatu hal yang statis karena mengacu pada standar yang telah ditentukan serta menghambat proses dinamis dari pengembangan dan peningkatan mutu. Namun problem tersebut biasanya hanya muncul kalau implementasi sistem mutunya buruk. Suatu sistem mutu yang efektif akan mendorong perbaikan mutu secara dinamis sebagai interaksi antara audit mutu internal, tindakan koreksi dan tinjauan menajemen dan perubahan sistem. Audit mutu internal mengidentifikasi kelemahan-kelemahan yang diketahui melalui tindakan koreksi dan untuk rekomendasi perubahan. Rekomendasi dipertimbangkan dalam tinjauan manajemen dan perubahan dalam sistem mutu disepakati lalu diterapkan. Pada giliran berikutnya prosedur-prosedur yang telah ditinjau ulang tadi diaudit kembali dan kalau masih terdapat kekurangan disana-sini, proses diatas diulang kembali.

\section{KINERJA KEUANGAN PERUSAHAAN}

Tujuan dari perusahaan adalah memaksimumkan nilai perusahaan. Dalam mencapai nilai yang diinginkan, perusahaan hendaklah mengkombinasikan antara keunggulan dan kelemahan yang dia miliki serta dengan memantau secara terus menerus peluang serta ancaman yang akan dia hadapi. Salah satu indikator dari keuangan untuk melihat kinerja yang dihasilkannya adalah laporan keuangan.

Laporan keuangan inilah yang digunakan oleh perusahaan untuk memonitor kondisi keuangan perusahaan. Van Horne dan Markowictz (1997: 133) mengemukakan bahwa untuk mengevaluasi kondisi keuangan dan kinerja keuangan, analisis keuangan harus melakukan pemeriksaan terhadap kondisi keuangan perusahaan. 
Alat yang biasa dipakai untuk menilai kinerja keuangan adalah ratio keuangan atau index. Penggunaan alat ini dengan menghubungkan dua data keuangan dengan jalan membagi satu data dengan data lainnya. Laporan keuangan melaporkan prestasi historis dari perusahaan serta memberikan dasar dengan berbagai pertimbangan analis bisnis serta ekonomi untuk membuat proyeksi dan peramalan untuk masa yang akan datang. Pemanfaatan laporan keuangan lainnya adalah sebagai bahan evaluasi kinerja keuangan perusahaan yang pada akhirnya akan memberikan kompensasi kepada para partisipan (Westond, 1995:24)

\section{Earning Per Share (EPS)}

Kinerja keuangan dapat dianalisis dengan earning per share(EPS). Earning per share merupakan perbandingan antara laba bersih setelah pajak pada satu tahun buku dengan jumlah saham yang diterbitkan (outstanding shares). Laba bersih setelah pajak ini biasa disebut nett income after tax. Dalam pasar modal, pemodal seringkali memusatkan perhatian pada laba per saham (earning per share) dalam melakukan analisis. Angka earning per share ini biasanya disajikan paling bawah dalam laporan rugi laba (Westond, 1995: 238)

Angka earning per share ini diperoleh dari laporan keuangan yang disajikan oleh perusahaan berdasarkan atas prinsip-prinsip akuntansi yang umum diterima. Earning per share mencerminkan kombinasi berbagai faktor yang mempengaruhinya. Earning per share merupakan perbandingan antara laba bersih setelah pajak pada satu tahun buku dengan jumlah saham yang diterbitkan (outstanding shares). Dari rumus tersebut, maka dapat kita lihat bahwa semakin besar deviden yang dibagikan maka EPS akan semakin kecil atau semakin kecil NIAT (Net Income After Tax) maka akan semakin kecil pula EPS. Jumlah saham yang diterbitkan berbanding terbalik dengan EPS, artinya semakin besar jumlah saham yang diterbitkan semakin kecil EPS demikian juga sebaliknya.

\section{METODE}

\section{Populasi}

Populasi dalam penelitian ini adalah perusahaan makanan dan minuman di Indonesia yang telah melakukan Initial Public Offering (IPO). Perusahaan 
makanan dan minuman di Indonesia yang telah melakukan IPO dan melakukan perdagangan secara aktif dalam kurun waktu 1994 sampai dengan 2005. Jumlah perusahaan makanan dan minuman yang telah melakukan IPO dan sahamnya aktif diperdagangkan berjumlah 13 perusahaan. Dan yang telah mendapatkan sertifikasi ISO 9000 sejumlah 5 perusahaan. Dipilihnya perusahaan yang telah melakukan initial public offering dengan pertimbangan, bahwa perusahaan yang telah melakukan IPO secara tidak langsung dikontrol oleh masyarakat (pemegang saham) atau public. Sehingga perusahaan terus berusaha menjaga dan menjamin kinerja keuangannya secara terus menerus demi perkembangan perusahaan.

Peneliti tertarik untuk mengadakan penelitian pada perusahaan makanan dan minuman yang telah melakukan IPO di Indonesia dengan pertimbangan sebagai berikut :

1. Produk makanan dan minuman merupakan produk yang sangat diperlukan oleh masyarakat dalam rangka memenuhi kebutuhan sehari-hari.

2. Dalam kondisi apapun masyarakat tetap mengkonsumsinya untuk kelangsungan hidupnya

Karena jumlah populasinya kecil, maka peneliti mengambil keseluruhan populasi untuk diteliti, yaitu 13 perusahaan makanan dan minuman. Data yang digunakan dalam penelitian ini dimulai tahun 1994 sampai dengan 2006. Perusahaan makanan dan minuman di Indonesia yang telah melakukan initial public offering adalah sebagai berikut :

1. Ades Alfindo Putra Setia

2. Aqua Golden Mississipi

8. Prasidha Aneka Niaga

3. Davomas Abadi

9. Sari Husada

4. Delta Djakarta

10. Sekar Laut

5. Indofood Sukses Makmur

11. Smart Coorporation

6. Mayora Indoah

12. Suba Indah

7. Multi Bintang Indonesia

13. Ultra Jaya Milk

Sumber : Jakarta Stock Exchange, 1994-2006

Sedangkan perusahaan makanan dan minuman di Indonesia yang telah mendapatkan sertifikasi ISO 9000 adalah sebagai berikut : 
Tabel .

Daftar Perusahaan Makanan Dan Minuman Di Indonesia Yang Telah Mendapatkan Sertifikasi ISO 9000

\begin{tabular}{|r|c|}
\hline Perusahaan makanan dan minuman di Indonesia & Tahun \\
\hline 1. Aqua Golden Mississipi & 1994 \\
2. Indofood Sukses Makmur & 1994 \\
3. Sari Husada & 1995 \\
4. Smart Coorporation & 1996 \\
5. Suba Indah & 1995 \\
\hline
\end{tabular} Sumber : Departemen Perindustrian dan Perdagangan Jawa Timur,
2006

\section{Metode pengumpulan Data}

Data yang digunakan dalam penelitian ini adalah data sekunder yang berupa laporan keuangan dari perusahaan yang bersangkutan yang berupa laporan rugi laba serta jumlah saham yang diterbitkan serta daftar perusahaan yang telah mendapatkan sertifikasi ISO 9000. Data bersumber dari Bursa Efek Jakarta. Departemen Perindustrian dan Perdagangan, serta publikasi resmi dari lembaga pemerintah, swasta atau lembaga lain yang relevan.

\section{Identifikasi dan Definisi Operasional Variabel}

Variabel yang akan diteliti dalam penelitian ini adalah :

* Variabel terikat:

- Earning per share yang didapat dari Nett Income After Tax (NIAT) dibagi dengan Outstanding Shares (total saham yang diterbitkan).

* Variabel Bebas :

- Setifikasi ISO 9000, dengan mengelompokkannya dalam 4 kelompok.

Pengelompokan ini dengan pertimbangan bahwa dimungkinkan bahwa lamanya suatu perusahaan dalam memegang sertifikasi ISO 9000 akan memengaruhi performance perusahaan. Keempat kelompok tersebut adalah sebagai berikut :

a. Kelompok yang tidak bersertifikasi ISO 9000 dengan notasi 0

b. Kelompok yang bersertifikasi ISO 9000 berdasarkan tahun kepemilikan pertama dengan notasi 1

c. Kelompok yang bersertifikasi ISO 9000 berdasarkan tahun kepemilikan kedua dengan notasi 2 
d. Kelompok yang bersertifikasi ISO 9000 berdasarkan tahun kepemilikan ketiga dengan notasi 3

\section{Metode Analisis}

\section{Uji ANOVA}

Untuk menjawab rumusan masalah yang dikemukakan, maka penelitian ini menggunakan metode statistik Analisis Variansi (ANOVA). Analisis ini dikembangkan dan diperkenalkan pertama kali oleh Sir Ronald A. Fisher. Analisis ini digunakan untuk menguji apakah dua atau lebih rata-rata populasi yang tidak diketahui adalah sama. Anova memiliki kelebihan dan kekurangan dibandingkan dengan uji hipotesis beda dua rata-rata. Kelebihan ANOVA adalah :

1. ANOVA dapat menguji beda lebih dari dua rata-rata populasi secara simultan

2. ANOVA dapat memasukkan lebih dari dua perlakuan ke dalam pengujian.

Dalam ANOVA, hipotesis yang menyatakan bahwa semua rata-rata sample berasal dari populasi dengan rata-rata yang sama dapat diuji pada kondisi sebagai berikut :

1. Semua sampel dipilih secara random dan independent antara sample yang satu dengan sample yang lain

2. Populasi dari sample yang digunakan berdistribusi normal

3. Semua populasi mempunyai varians yang sama.

Dalam penelitian ini diberikan satu perlakuan (treatment), yaitu sertifikasi ISO 9000 dengan mengklasifikasikannya menjadi 4, yaitu :

- Kelompok yang tidak bersertifikasi ISO 9000 dengan notasi 0

- Kelompok yang bersertifikasi ISO 9000 berdasarkan tahun kepemilikan pertama dengan notasi 1

- Kelompok yang bersertifikasi ISO 9000 berdasarkan tahun kepemilikan kedua dengan notasi 2

- Kelompok yang bersertifikasi ISO 9000 berdasarkan tahun kepemilikan ketiga dengan notasi 3 
Sehingga dalam penelitian ini menggunakan ANOVA satu arah (one-way ANOVA). Posedur pengujian hipotesis dengan menggunakan ANOVA terdiri dari langkah-langkah sebagai berikut, yaitu:

1. Rumusan Hipotesis

Ho $: \mu 1=\mu 2=\mu 3$

HA : Tidak semua rata-rata populasi sama

2. Menentukan nilai kritis

Informasi untuk menentukan nilai kritis adalah tingkat signifikansi yang digunakan dalam pengujian dan degree of fredom (d.f) yang besrnya adalah (k-1) (n-k). Tingkat signifikansi yang digunakan biasanya 1\%, $5 \%$ atau $10 \%$

3. Menentukan Nilai Hitung:

$$
F=\frac{M S B}{M S W}
$$

Analisis pasca ANOVA :

Penolakan terhadap hipotesis nol dalam perbandingan sejumlah rata-rata industri, berarti kita menyimpulkan bahwa paling sedikit ada dua buah ratarata populsi yang berbeda satu sama lain. Setelah ANOVA menolak hipotesis seluruh kelompok yang berasal dari populasi yang sama, persoalan berkutnya adalah kelompok mana yang berasal dari populasi yang berbeda. Maka kita perlu melakukan uji lanjutan. Maksud mengadakan uji lanjutan adalah :

a. Untuk mendapatkan informasi lebih lanjut dari nilai tengah-nilai tengah perlakuan yang dicobakan setelah sebelumnya diuji dengan uji ANOVA. Karena uji ANOVA tidak dapat menunjukkan perlakuan mana saja yang berbeda.

b. Tujuan akhir yang hendak dicapai melalui uji lanjutan adalah membantu memberikan interpretasi dari berbagai perlakuan yang dicobakan sehingga kesimpulan yang diambil dapat memiliki presisi yang tinggi.

\section{Uji Duncan's}

Banyak tehnik yang telah dikembangkan untuk memecahkan dan menjawab persoalan tersebut, salah satunya adalah dengan uji jarak nyata 
Duncan's, Uji Duncan's ini digunakan untuk memecahkan masalah ke tiga dengan formulasi sebagai berikut :

$$
J N T a=J D N a(P: \text { dbgalat }) x \frac{K T G}{\text { ulangan }}
$$

\section{Uji Korelasi}

Analisis ini digunakan untuk mengetahui hubungan antara sertifikasi ISO 9000 dengan Earning Per Share (EPS) dengan menggunakan analisis Korelasi Rank Spearman's. Alat ini digunakan untuk mengetahui keeratan hubungan antara dua variabel yang sulit diukur numeriknya. Korelasi rangking spearman dapat digunakan untuk mengetahui korelasi (hubungan) antara dua variabel yang sulit diukur nilai numeriknya dengan membuat rangking dari masingmasing variabel tersebut. Ukuran keeratan hubungan antara dua variabel tersebut dapat diketahui melalui koefisien korelasi rangking.

Besarnya koefisien korelasi rangking dapat dihitung dengan menggunakan fomula sebagai berikut:

$$
r s=\frac{1-6 \sum d^{2}}{n(n-1)^{2}}
$$

Dimana:

$$
\begin{aligned}
\mathrm{rs} & =\text { koefisien korelai rangking Spearman } \\
\mathrm{n} & =\text { banyaknya pasangan data } \\
\Sigma & =\text { notasi jumlah } \\
\mathrm{d} & =\text { perbedaan rangking antara pasangan data }
\end{aligned}
$$

\section{HASIL DAN PEMBAHASAN}

Tabel 2

Rata-Rata Earning Per Share Tahun 1994 - 2005

\begin{tabular}{|c|c|c|c|}
\hline Variabel EPS & $\mathbf{N}$ & Rata-Rata & $\mathbf{0}$ \\
\hline 0 & 96 & 622,4896 & 27.21 \\
1 & 24 & $1.453,1250$ & 63.51 \\
2 & 22 & 228,5000 & 9.99 \\
3 & 10 & $-15,7000$ & -0.69 \\
\hline
\end{tabular}

Sumber : data diolah

Keterangan:

0 : Perusahaan yang tidak mempunyai sertifikasi ISO 9000

1 : Perusahaan yang mendapatkan sertifikasi ISO 9000 tahun 1994

2: Perusahaan yang mendapatkan sertifikasi ISO 9000 tahun 1995

3 : Perusahaan yang mendapatkan sertifikasi ISO 9000 tahun 1996 
Berdasarkan tabel diatas secara rinci diketahui rata-rata dari earing per share pada tahun 1994 - 2006 sebagai berikut:

Rata-rata prosentase perusahaan yang tidak mempunyai sertifikasi ISO 9000 mengalami kenaikan sebesar 27,21\% kenaikan tersebut relatif lebih kecil jika dibandingkan dengan prosentase rata-rata kenaikan penjualan perusahaan yang telah mempunyai sertifikat ISO 9000 untuk tahun 1994 karena mengalami prosentase peningkatan terbesar yaitu 63,51\%, kecuali untuk perusahaan yang mendapatkan sertifikasi ISO 9000 untuk tahun 1995 mengalami prosentase peningkatan sebesar 9,99\%, serta untuk perusahaan yang telah mendapatkan sertifikasi ISO 9000 untuk tahun 1996 mengalami prosentase penurunan sebesar $0,69 \%$.

\section{a. Uji ANOVA}

Menjawab masalah yang kedua, yaitu melihat perbedaan earning per share antar perusahaan makanan dan minuman yang bersertifikasi ISO 9000 dan perusahaan makanan dan minuman yang tidak memiliki sertifikat ISO 9000 menggunakan analisis varian (ANOVA) yang ditunjukkan pada tabel 4 sebagai berikut:

\section{Tabel 3}

ANOVA

\begin{tabular}{|l|l|l|l|c|c|}
\hline $\begin{array}{c}\text { SUMBER } \\
\text { KERAGAMAN }\end{array}$ & \multicolumn{1}{|c|}{$\mathbf{d b}$} & \multicolumn{1}{|c|}{ JK } & KT & F & Sig. \\
\hline Antar group & 3 & 24384509 & 8128169,753 & 3,916 & 0,010 \\
\hline Dalam group & 148 & $3.07 \mathrm{E}+08$ & 2075404,893 & & \\
\hline Total & 151 & $3.32 \mathrm{E}+08$ & & & \\
\hline
\end{tabular}

Sumber : data diolah

Berdasarkan tabel 4 diketahui bahwa diperoleh $\mathrm{f}$ hitung sebesar 3,916 dengan signifikansi sebesar 0,010 karena nilai signifikansi dibawah 0,05 maka berarti terdapat perbedaan EPS dari perusahaan yang tidak memiliki ISO 9000 dengan perusahaan yang mendapatkan ISO 9000 tahun 1994, 1995 dan 1996.

\section{b. Uji Duncan's}

Untuk mengetahui sejauh mana perbedaan dapat dilihat dengan menggunakan analisis lanjutan dengan menggunakan uji Duncan sebagai berikut: 
Tabel 4

Hasil Uji Duncan

\begin{tabular}{|c|c|c|c|c|}
\hline $\begin{array}{c}\text { Variabel } \\
\text { EPS }\end{array}$ & $\mathbf{N}$ & Rata-Rata & \multicolumn{2}{|c|}{ Subset dg alpha = 0,05 } \\
\cline { 4 - 5 } & & & $\mathbf{1}$ & $\mathbf{2}$ \\
\hline 3 & 10 & $-15,7000$ & $\mathrm{~A}$ & \\
\hline 2 & 22 & 228,5000 & $\mathrm{~A}$ & $\mathrm{~B}$ \\
\hline 0 & 96 & 622,4896 & $\mathrm{~A}$ & $\mathrm{~B}$ \\
\hline 1 & 24 & $1.453,1250$ & & 0,067 \\
\hline Sig. & & & 0,161 & \\
\hline
\end{tabular}

Sumber : data diolah

Keterangan:

0 : Perusahaan yang tidak mempunyai sertifikasi ISO 9000

1 : Perusahaan yang mendapatkan sertifikasi ISO 9000 tahun 1994

2 : Perusahaan yang mendapatkan sertifikasi ISO 9000 tahun 1995

3: Perusahaan yang mendapatkan sertifikasi ISO 9000 tahun 1996

Berdasarkan hasil uji Duncan dapat diketahui bahwa keempat kategori perusahaan diatas dapat dibedakan menjadi dua kelompok, pertama perusahaan yang mendapat ISO 1996, 1995 dan yang tidak mendapat sertifikasi ISO 9000. Hal ini disebabkan perusahaan yang tidak mempunyai sertifikasi ISO 9000 (Mayora Indo, Sekar Laut, Ultra Djaya Milk Industri, Ades Alfindo, Davomas Abadi dan Prasidina Aneka Niaga) dan perusahaan yang mendapatkan ISO 9000 tahun 1995 dan 1996 memiliki nilai rata-rata earning per share yang berdekatan atau satu kelompok.

Sedangkan kelompok kedua adalah perusahaan yang tidak mendapatkan sertifikasi ISO 9000 dan perusahaan yang mendapatkan ISO 1994. Hal ini berarti terdapat beberapa perusahaan yang belum mendapatkan ISO 9000 namun memiliki nilai EPS yang tinggi yaitu perusahaan Delta Djakarta dan Multi Bintang Indo

\section{c. Analisis Korelasi}

Untuk mengetahui hubungan antara sertifikasi ISO 9000 dengan Earning Per Share dengan menggunakan analisis Korelasi Rank Spearman's diperoleh hasil sebagai berikut: 
Tabel 5

Hasil Analisis Korelasi Rank Spearman's

\begin{tabular}{|c|c|c|}
\hline Variabel & Korelasi Rank Spearman's & Sig. \\
\hline EPS dengan 0 & $-0,069$ & 0,397 \\
EPS dengan 1 & 0,229 & 0,005 \\
EPS dengan 2 & $-0,088$ & 0,279 \\
EPS dengan 3 & $-0,077$ & 0,347 \\
\hline
\end{tabular}

Sumber : data diolah

Keterangan:

0 : Perusahaan yang tidak mempunyai sertifikasi ISO 9000

1 : Perusahaan yang mendapatkan sertifikasi ISO 9000 tahun 1994

2 : Perusahaan yang mendapatkan sertifikasi ISO 9000 tahun 1995

3 : Perusahaan yang mendapatkan sertifikasi ISO 9000 tahun 1996

Berdasarkan tabel 6 diketahui bahwa hubungan antara perusahaan yang tidak mempunyai sertifikasi ISO 9000 dengan earning per share sebesar -0,069 dengan signifikansi 0,397 karena nilai signifikansi diatas 0,05 maka hubungan ini dapat dikatakan bahwa tidak terdapat hubungan negatif antara perusahaan yang tidak mempunyai sertifikasi ISO 9000 dengan earning per share.

Sedangkan hubungan antara perusahaan yang mendapat sertifikasi ISO 9000 tahun 1994 dengan earning per share sebesar 0,229 dengan signifikansi 0,005 karena nilai signifikansi dibawah 0,05 maka hubungan ini dapat dikatakan bahwa terdapat hubungan positif antara perusahaan yang mendapat sertifikasi ISO 9000 tahun 1994 dengan earning per share.

Sedangkan hubungan antara perusahaan yang mendapat sertifikasi ISO 9000 tahun 1995 dengan earning per share sebesar -0,088 dengan signifikansi 0,279 karena nilai signifikansi diatas 0,05 maka hubungan ini dapat dikatakan bahwa tidak terdapat hubungan negatif antara perusahaan yang mendapat sertifikasi ISO 9000 tahun 1995 dengan earning per share.

Sedangkan hubungan antara perusahaan yang mendapat sertifikasi ISO 9000 tahun 1996 dengan earning per share sebesar -0,077 dengan signifikansi 0,347 karena nilai signifikansi diatas 0,05 maka hubungan ini dapat dikatakan bahwa tidak terdapat hubungan positif antara perusahaan yang mendapat sertifikasi ISO 9000 tahun 1996 dengan earning per share.

\section{KESIMPULAN DAN SARAN}

\section{Kesimpulan}


Berdasarkan analisis hasil penelitian yang telah dikemukakan, maka dapat datarik kesimpulan sebagai berikut :

1) Rata-rata prosentase perusahaan yang tidak mempunyai sertifikasi ISO 9000 mengalami kenaikan sebesar 27,21\% kenaikan tersebut relatif lebih kecil jika dibandingkan dengan prosentase rata-rata kenaikan penjualan perusahaan yang telah mempunyai sertifikat ISO 9000 untuk tahun 1994 karena mengalami prosentase peningkatan terbesar yaitu 63,51\%, kecuali untuk perusahaan yang mendapatkan sertifikasi ISO 9000 untuk tahun 1995 mengalami prosentase peningkatan sebesar 9,99\%, serta untuk perusahaan yang telah mendapatkan sertifikasi ISO 9000 untuk tahun 1996 mengalami prosentase penurunan sebesar $-0,69 \%$.

2) Berdasarkan analisis ANOVA diketahui bahwa diperoleh $f$ hitung sebesar 3,916 dengan signifikansi sebesar 0,010 karena nilai signifikansi dibawah 0,05 maka berarti terdapat perbedaan EPS dari perusahaan yang tidak memiliki ISO 9000 dengan perusahaan yang mendapatkan ISO 9000 tahun 1994, 1995 dan 1996.

3) Berdasarkan hasil uji Duncan dapat diketahui bahwa keempat kategori perusahaan diatas dapat dibedakan menjadi dua kelompok, pertama perusahaan yang mendapat ISO 1996, 1995 dan yang tidak mendapat sertifikasi ISO 9000. Hal ini disebabkan perusahaan yang tidak mempunyai sertifikasi ISO 9000 (Mayora Indo, Sekar Laut, Ultra Djaya Milk Industri, Ades Alfindo, Davomas Abadi dan Prasidina Aneka Niaga) dan perusahaan yang mendapatkan ISO 9000 tahun 1995 dan 1996 memiliki nilai rata-rata earning per share yang berdekatan atau satu kelompok. Sedangkan kelompok kedua adalah perusahaan yang tidak mendapatkan sertifikasi ISO 9000 dan perusahaan yang mendapatkan ISO 1994. hal ini berarti terdapat beberapa perusahaan yang belum mendapatkan ISO 9000 namun memiliki nilai EPS yang tinggi yaitu perusahaan Delta Djakarta dan Multi Bintang Indo.

4) Berdasarkan analisis korelasi rank spearmen's diketahui bahwa earning per share perusahaan mempunyai hubungan dengan sertifikasi ISO 9000 (untuk perusahaan yang mendapatkan sertifikasi ISO 9000 pada tahun 1994) 


\section{Saran}

1. Agar perusahaan kompetitif di pasarnya, diminati dan dapat menciptakan loyalitas pelanggan, maka perusahaan harus selalu melakukan penyegaran, pembenahan internal tanpa harus menunggu tuntutan pihak luar

2. Dalam melaksanakan klausal yang terdapat dalam sertifikasi ISO 9000 diperlukan dukungan secara penuh dari semua karyawan serta keterlibatan langsung dari manajer eksekutif terutama dalam pengembangan berkelanjutan dari para personil, proses dan sistem yang dimiliki

3. Sertifikasi ISO tidaklah akan memberikan manfaat apa-apa apabila perusahaan tidak mau berubah.

4. Sertifikasi ISO 9000 bukanlah satu-satunya senjata untuk meningkatkan penjualannya, sehingga berpengaruh pada earning per share perusahaan. Kinerja keuangan yang cemerlang merupakan hasil dari sinergi dari berbagai kekuatan yang dimiliki oleh perusahaan sehingga dapat berdampak pada perluasan pangsa pasar yang akhirnya akan meningkatkan laba perusahaan, yang pada akhirnya berpengaruh terhadap earning per share perusahaan.

5. Kinerja keuangan yang gemilang merupakan kesatuan dari berbagai kekuatan yang dimiliki oleh perusahaan. Perusahaan berusaha dan bekerja keras untuk mencapainya. Sertifikasi ISO 9000 merupakan salah satu pendukung agar perusahaan mencapai sukses yang gemilang. Tanpa adanya kesungguhan dan konsistensi perusahaan dalam menerapkan klausal yang ada dalam sertifikasi itu mustahil keberhasilan dapat dicapai. Kepedulian dan kesungguhan serta konsistensi dari seluruh personil yang ada di perusahaan merupakan salah satu kunci utama untuk melaksanakannya. Tanpa itu semua mustahil hasil yang gemilang akan tercapai.

6. Untuk penelitian selanjutnya, peneliti menyarankan agar data yang dipergunakan gabungan data sekunder serta data primer, hal ini dimungkinkan untuk mendapatkan hasil yang lebih komprehensif 
7. Penelitian selanjutnya diharapkan dengan tinjauan yang lebih luas, misalnya dengan menambah variabel yang diteliti atau dengan mengembangkan populasi.

\section{DAFTAR PUSTAKA}

Al-Quran. surat Al- Baqarah

Darmawan, Thomas. 1999. Bulog Tetap Dibutuhkan. Usahawan, No 12 Tahun XXVIII Desember.

Hadijoewono, Handito. 1995. Kiat Agar Konsumen Tidak Kabur. Majalah Manajemen, Mei-Juni.

Harbunangin, Harahap. 1995. Tiga Hal Penting Tentang ISO 9000. Cetakan ke 1. Jakarta: PT Iron Damwin Santoso.

Herdiwiardjo, Bambang dan Sulistijarningsih Wibisono. 1996. ISO 9000 Sistem Manajemen Mutu. Jakarta: Ghalia Indonesia.

Ibrahim, Buddy. 1997. Total Quality Management (TQM) Panduan Untuk Menghadapi Persaingan Global. Jakarta: Penerbit Djambatan.

Jakarta Stock Exchange. 1994-2006

Krajewski, Lee J and Larry P.Ritzman. 1996. Operations Management Strategy and Analysis. Fourt Ediyion. Addison-Wesley Publising Company. Inc.

Montogomery, Douglas. 1998. Pengantar Pengendalian Kualitas Statistik. Yogyajarta: Gajah Mada Universty Press.

Sagir. Soeharsono. 1997. Antisipasi Perdagangan Bebas : Ekonomi Biaya Tinggi. Kehandalan Tehnologi dan Daya Saing. Majalah Usahawan, No.9 Tahun XXVI (September).

Soemardi. P. 1992. Berpacu dalam AFTA. Majalah Usahawan, No 12 Tahun XXI Desember.

Surveyor. 1996. Pengenalan ISO 9000. PT Surveyor Indonesia

Tjiptono. Fandy dan Anastasia Diana. 2000. Total Quality Management. Edisi Kedua. Yogyakarta: Andi Offset.

Westond. J Fred and Thomas E. Copeland. 1995. Manajemen Keuangan. Edisi Kesembilan, Jilid 1. Binarupa Aksara.

Westond, J Fred and Eugene F. Brigham. 1998. Manajemen Keuangan, Edisi IX. PT Gelora Aksara Pratama.

Wibisono, Dermawan . 1999. Analisis Keterkaitan Variabel Kinerja dalam Perusahaan. Majalah Usahawan, No 07 TH XXVIII (Juli).

Yamit, Zulian. 1998. Manajemen Produksi dan Operasi. Edisi pertama Cetakan kedua. PT Surya Sarana Utama. 